https://doi.org/10.18485/unislav.2017.ch31

821.163.41.03-97=111

811.163.41'276:271.2

811.111'276:27

27-29 Велимировић Н.

\author{
ИВАНА КНЕЖЕВИЋ ${ }^{*}$ \\ Православни богословски факултет Универзитета у Београду \\ Београд, Србија

\section{ЦРКВЕНОСЛОВЕНИЗМИ У РАДОВИМА ВЛАДИКЕ НИКОЛАЈА (ВЕЛИМИРОВИЋА) НА ЕНГЛЕСКОМ ЈЕЗИКУ}

\begin{abstract}
У културама различитих народа постоје реалије специфичне за дату заједницу, што се не језичком плану одражава у виду постојања безеквивалентне лексике. Овим радом настојали смо да сагледамо проблеме преводиоца у сусрету са безеквивалентном лексиком на изабраном корпусу владике Николаја на српском и енглеском језику у области православне вере и духовности. Поред тога, поменућемо и питање одступања од правописне норме у радовима православне вере и духовности.
\end{abstract}

Кључне речи: превођење, безеквивалентна лексика, православна терминологија, позајмљенице, црквенословенизми, преводилачки поступци

Разлике међу језицима које настају као последица различитих култура, посеб̆о долазе до изражаја на плану вокабулара. У сваком језику постоје речи које немају један одговарајући преводни еквивалент у другом језику. Разлог овоме јесте постојање појмова и предмета који су карактеристични за једну културу, односно један народ. Безеквивалентна лексика односи се на називе за одређене реалије које немају своје потпуне еквиваленте у неком другом језику. Проблеми у вези са безеквивалентном лексиком уочљиви су при додирима различитих култура, а са њима се суочавају преводиоци који настоје да пронађу најбоље решење за овакве проблеме. Овај рад бави се питањима превођења безеквивалентне лексике на енглески језик у области терминологије православне Цркве, с посебним освртом на употребу позајмљеница из црквенословенског у енглеском језику.

Треба истаћи и да је за радове из области православне духовности карактеристична специфична употреба великог слова која није у потпуности у складу са правописном нормом, посеб́о у радовима српском језику. Запажа се и недоследност у њеној примени, често и у једном истом

*ivanaknezevicbg@gmail.com 
тексту, како српског тако и енглеског језика (почецима анализе писања великог слова у сакралном корпусу в. Knežević, Ranković 2014: 38-51). Начелно можемо говорити о постојању правописног стандарда на нивоу религиолекта (православног, у овом случају) који се примењује на обликовање текстова религијске оријентације, с једне стране и постојању стандарда који се остварује у секуларним текстовима, с друге стране (Кончаревић 2009: 11-38). Реч је о употреби великог слова код писања

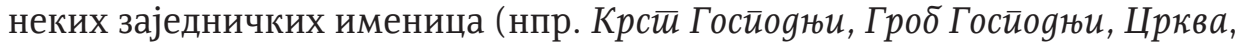
и сл); заменица, личних пре свега али и присвојних, показних и односних, које се односе на Христа, Богородицу и Свету Тројицу; теонима - назива за Бога, Богородицу, Свету Тројицу, као и за придев изведен од именице Бог (Божији); атрибута у именима светитеља; чин светости; титуле свештених лица; звања верских поглавара; еклисионима (Светии Сава, ирква Свет̄ог̄ Саве); иконима (називи икона); назива административних јединица; назива припадника религија. Сакрални ортографски стандард не подудара се увек са правописном нормом када је реч о употреби великог слова у писању неких горе побројаних појмова. Одступања од норме, тј. чешће прибегавање употреби великог слова при писању одређених класа речи (првенствено агионима) изразити су маркери религијских текстова. Ово посебно важи за сакрални стандард српског језика, док је у енглеском језику према општејезичкој норми употреба великог слова фреквентнија него у општејезичкој норми српског језика, па ове разлике у сакралној сфери енглеског језика јесу мање упадљиве, али не треба их занемаривати.

Употреба великог слова је модалног карактера, и у складу је са ауторовим односом према предмету о коме говори и његовом конотативном димензијом. Обележавање великим словом донекле је факултативно и може се сматрати емоционалним и експресивним средством. Велико слово доноси собом додатни садржај - не само у виду емоционалних, већ и валоризаторских информација. Осећа се посебна потреба да се великим словом истакне необухватност, надсазнајност духовних појмова и категорија и њихова различитост у односу на појаве опипљиве стварности. То је и разлог шароликости у употреби великог слова како у српском тако и у енглеском тексту. Не би се требало помирити са констатацијом у Правойису срйскої језика да писање великог слова у оним стиловима у којима се то примењује као посебна обележеност израза и стилистичко средство, а да би се постигао посебан утисак (где се пре свега у виду има верски маркирани текст) није предмет језичког и правописног нормирања, посебно кад се истовремено указује на примере измене правила писања великог слова код оних питања који су „обрађена и разрађена" (Пешикан, Јерковић, Пижурица 2009: 38; 40). Постојећа неуједначеност и недоследност у употреби великог слова требало би да 
буде узета у разматрање и регулисана нормом. Ипак, где је то нужно треба оставити и могућност толерисања „дублета” - алтернативних могућности. Међутим, и ова флексибилност требало би да буде сведена на најмањи могући степен.

Посебан проблем када је реч о превођењу са енглеског на српски представљају дублети, односно „црквени термини засновани на западној и источној варијанти језика", односно београдској и загребачкој норми. Овакви дублети постоје у општем речнику српског језика, за разлику од енглеског где су православне варијанте познате само некима (православним верницима) и стручним круговима. Ако се у тексту који се преводи са енглеског јавља већи број неутралних или „конфесионално необележених", немаркираних термина преводилац мора бити обазрив при избору између дублета који постоје у српском језику. Реч је о реалијама које у сличном или истом облику постоје у другим хришћанским црквама, као што су титуле, појединим комади црквене одежде, богослужења, обреди, и сл. Анализираћемо неколико примера.

Термину bishop, који у енглеском оригиналу није ближе објашњен придевом Orthodox, односно Roman Catholic bishop, у српском могу одговарати два еквивалента, ейиской и $\delta и с к у \bar{u}$. Уколико се ради о православном црквеном великодостојнику преводилац треба да употреби

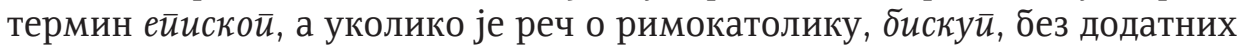
објашњења јер ће просечни прималац превода знати о којој је конфесији реч. У том случају употреба придева йравославни уз термин $\boldsymbol{e} \bar{u} и с к о \bar{u}$ биће редундантна. Исто важи и за случај римокайолички бискуй.

У српском језику постоји разлика између јектиеније и литианије, док енглески језик оба преводи речју litany, уколико не узмемо у обзир поменуте стране речи (ectenia, ektene, ektenia) које прецизно одређују „конфесионалну боју” термина.

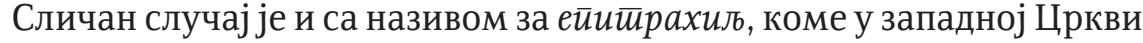
одговара термин сишола. Енглески језик ће најчешће користити термин stole, који је као и већина верских термина у енглески језик дошла из латинског посредством римокатолицизма. Добар преводилац текста из области православне духовности и теологије, не би требало да се одлучи за израз стиола јер је „конфесионално обојен”. Овакви преводи показују недовољну образованост преводиоца и могу изгледати неумесно. Овде је веома важна добра информисаност и образовање самог преводиоца. Поред тога, преводилац не би требало да буде конфесионално обележен или „погрешно” мотивисан, и да кроз његов превод смислено а неоправдано провејава лексика обележена католичким, протестантским, православним или другим валером (Ракић 2002: 25-37).

Приликом превођења на енглески језик оних термина који се односе на комаде црквене одежде која не постоји у другим хришћанским Цр- 
квама користе се или стране речи, најчешће грчког порекла, или преводилац користи аналогне домаће називе. У другом случају, који је чешћи када се ради о просечним примаоцима превода, преводилац обично прибегава употреби оних термина који се односе на одежде католичке цркве, а који најчешће постоје као такви у општим речницима енглеског језика. Међутим, српски језик подвлачи разлику између православних

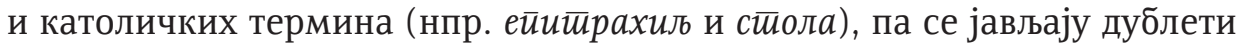
који у српском језику не могу бити схваћени као потпуни синоними.

chasuble (priest's garment: a loose sleeveless outer garment worn by a priest when celebrating Mass or Holy Communion), phelonion, felonion, felon, short tunic $=$ фелон

У делу који следи бавили смо се анализом превођења безеквивалентне лексике на примерима из одабраних радова владике Николаја. Посматрали смо конкретна решења која су поједини православни преводиоци, а у неким случајевима и сам аутор који је писао на енглеском, користили у превођењу или стварању датих текстова.

Полазећи од језика оригинала - српског језика, коме је православље изворно ближе него Англосаксонцима, настојали смо да утврдимо лексичке јединице којима је у преводу на енглески на неки начин покривено семантичко поље поменутих безеквивалентних лексема. Ради компаративног проучавања у анализу су укључена два дела владике Ни-

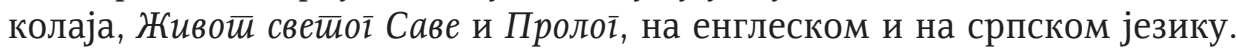
Анализа ће нам омогућити да утврдимо које је преводилачке поступке

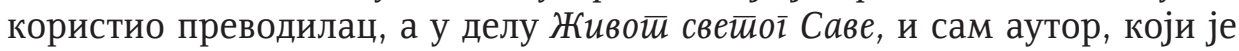
лично превео, тј. створио дело на енглеском језику.

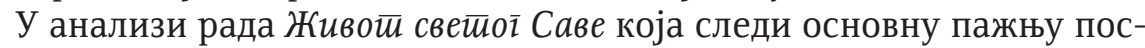
ветили смо варијанти на енглеском језику, будући да није у питању „превод” на енглески, јер га је сам писац оригинала створио. Међутим, с обзиром да је матерњи језик светог владике српски и да је у питању теолог, дакле одличан познавалац православне терминологије, ово дело смо ипак посматрали као преношење поменутих термина на енглески језик. Поред тога, бавили смо се и преводом „универзалних, општехришћанских термина", како бисмо извели закључке о оправданости употребе изабраних преводних поступака, односно еквивалената. У обзир смо узели врсту дела као и циљну читалачку публику.

Аутор одређене поруке, било да је она књижевна, новинска, разговорна, предагошка, информацијска, забављачка или нека друга, мора узети у обзир одређене податке о примаоцу поруке или реципијенту (Hlebec 1989: 70). Ти подаци укључују знање, искуство, укус и склоности, способности, узраст, друштвену и географску припадност, занимање, али, што је за овај рад посебно важно, културну и литерарну традицију у 
којој је прималац васпитаван. Преводилац сам одређује у којој ће мери сачувати националну самобитност дела пошто је претходно утврдио да ли његов претпостављени читалац познаје страну културу. Преводилац васпитава укус и образује свог примаоца новим информацијама које им пружа. Он може да утиче на ширење знања читаоца у области стране културе и да тако олакша пут пропагаторима те културе у својој земљи, па ће ови моћи да рачунају на упућенијег читаоца. У зависности од постојеће историјске ситуације преводилац може и да свесно допринесе зближавању или раздвајању двају култура (Levi 1982: 82-83). Ставу према примаоцу поруке је стваралачки, активан и промишљен, и преводилац развија жеље примаоца ако их нема, модификује ако су неоправдане са хуманистичког становишта, и поштује када су у стварном интересу примаоца (Hlebec 1989: 80).

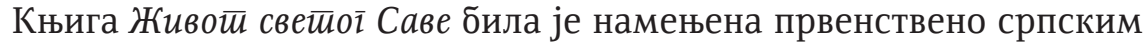
исељеницима и њиховим потомцима који су матерњи језик заборавили. Објављена је средином прошлог века у Сједињеним Америчким Државама у оригиналу на енглеском језику. Ово је била прилика да се српска историја, култура, народ и његова вера приближе човеку западне културе. Аутор поменутог дела сусрео се са проблемом не само удаљености културе српског народа и западног света, већ и са проблемом непросвећености, слабе или погрешне обавештености када је о православној вери реч.

У раду доминира употреба страних речи. Оне су позајмљене из грчког, црквенословенског или српског језика, и то су: Sveta Gora = Света Гора; the Prot (of Sveta Gora) = Прот - управник Свете Горе; Agiorites, Agiorite monk = светогорски монах; Agorite fathers = оци Свете Горе; heguman (pl. hegumans) = игуман; jeromonah = јеромонах; heparchos = епархос; Lavra = Лавра; Kinot = Синод; skyt (множина skytis, skyti) = скит; kelia $($ множина kellias $)=$ ћелије; Kelliots = монаси из ћелија; skytiots = монаси из скита; the Pateric (of Agion Oros) = анали (Свете Горе); Kapsokaliva (hut-burner) = Капсокаливија (паликућа); Konak = конак; paraceises $=$ помоћне цркве; fandarik = фандарик; metoch = метох; pergamun, chrysovulla = повеља; Isichastirion, Postnitza = испосница; Mislioniza $=$ мислионица; Karejski Typic = Карејски типик; Hilandar's Typic = Хиландарски Типик; Akathist = Акатист; Kyrie Eleison! = Господе, помилуј; archimandrite = архимандрит; pop = поп; protopop = протојереј; Grammata = грамата; Kormchija = Крмчија; Srbuljski = Србуље; $u$ kaze = указ; troparion = тропар; Spasovdan = Вазнесење Господње, Спасовдан; the Grat Entrance - Vhod = Велики вход; the Sabor = Cабор; Pateritza = палица; Vladika = Владика.

Горе наведене речи су прилагођене енглеском језику процесом: транслитерације, као нпр. речи Prot, Jeromonah, Lavra, Konak, fandarik, рор и др; транскрипције: chrysovulla, skytis , archimandrite, и др; или ком- 
бинациојм ова два поступка, такозваном „адаптираном транслитерацијом": Postnitza, Mislioniza, Isichastirion, и сл.

Владика Николај покушава да честом употребом страних речи приближи читаоцу културу, традицију и веру српског народа. Имајући у виду просечног примаоца превода, он је већину ових страних речи објаснио на два начина: а) у напомени на крају сваког поглавља, или б) додатним информацијама у самом тексту. Употреба само једног од ова два поступка унела би монотонију, и заморила просечног читаоца. Примери када је страна реч објашњена у напомени су следећи:

heguman (pl. hegumans) = игуман. Овај термин, који има своје еквиваленте у општем речнику језика превода, објашњава користећи такве аналогне домаће називе, Superior и Abbot, уз додатно објашњење ове титуле. Даље у тексту аутор ће користити позајмљеницу, настојећи да очува изворну референцу, али и поменуте аналогне домаће еквиваленте. На сличан начин објасниће у напомени и значење термина Grammata, пронашавши архаичан облик аналогног домаћег термина, Writ.

pergamun, chrysovulla = повеља. У овом случају дато је дословно значење на грчком, „златни печат”, и објашњена реалија на коју се односила.

Kormchija = Крмчија. У напомени даје буквално значење ове црквенословенске речи и на енглеском и на српском, “Book of Steering” или „кюиїa уирављањ $a^{\prime}$, уз додатне информације о њеном састављачу и пореклу података.

Аутор је ове стране термине користио не би ли потпуно очувао референцијално значење које оне имају у изворнику. Као добар познавалац језика, осетио је потребу не само да да̂ информације у напомени о датом термину, већ и да га дословно преведе.

Стране речи чије је додатно објашњење уткано у само ткиво текста представља следећу анализирану групу. Установили смо и издвојили три начина или форме ових додатака. Први начин је да се уз страну реч паралелно да̂ и аналогни домаћи назив за реалију која је најближа реалији изворника. Такви примери су следећи: Synod or Kinot = Синод; kelia or cell = ћелија; "...occupy the whole house, Konak" = конак; Hilandar's Typic or Rule = Хиландарски Типик; the Ascension of Our Lord, Spasovdan = Вазнесење Госйоgње, Сйасовgан; the Grat Entrance -Vhod = Велики вход; "He bequested his Staff, called Pateritza..." = палица; Овај термин додатно је и у напомени објашњен.

На једном месту каже да је свети Сава саставио Правила (= Rule), да је још увек сачуван и да се зове Карејски типик (= „Karejski Typic”), али даље у тексту користи само универзални термин Rule. 
Други начин да објасни страну реч у самом тексту јесте опис дате реалије, као у случају the High Praise "Akathist" = Акатист.

Srbuljski = Србуље ("He distributed to them books in the Serbian language - Srbuljski - he had brought from Sveta Gora.")

Помињући како је Сава створио јединствени дом за духовне вежбе и молитве ("home for spiritual exercises and worship") у Кареји на Светој Гори, каже да се „таква кућа на грчком зове 'Isichastirion' - што значи Кућа шичшине (House of Silence). Срби га зову Испосница ('Postnitza')". Касније у тексту наставља да користи и термин Postnitza и the Serbian House of Silence. Само у енглеској варијанти он у напомени додаје: "The House of Silence has been called in Serbian, 'Mislioniza', which means the 'House of Thinking'".

Ово је истовремено и пример за трећи начин да се додатно објасни одређени страни термин, а то је употреба буквалног превода или калка.

Поред страних речи, владика Николај прибегавао је и употреби калка без додатних објашњења за именовање реалија присутних само у православној цркви. Такав је случај са називима двају православних икона Пресвете Богородице, где је калкирање извршено са српског, односно црквенословенског језика: the Mother of God the Three-armed = Богородица Тројеручица; the Mother of God the Milk-giver = Богородица Сластопитатељница; као и: spiritual father = духовни отац; desert fathers = пустињски оци; the black-garbed = црнорисци.

Превод-дефиницију или описни превод налазимо, на пример у случајевима: patron saint = крсна слава; annual celebration (of St Simeon's day) = слава (Св. Симеона); black robed monks = монаси, црнорисци.

Од аналогних домаћих назива који истовремено неминовно неутралишу специфичан валер термина из културе изворника поменућемо следеће: garb = риза; feast = слава; abbot, superior, supreme superior = игуман, старешина у манастиру.

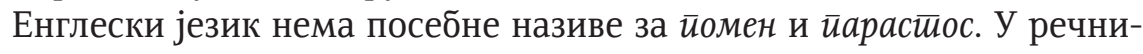
цима налазимо на позајмљенице из грчког, док у овом делу аналогни домаћи еквивалент, commemoration service, покрива оба поља значења.

Од семантичких неологизама издвајамо: the Fathers = свети оци. Овај термин својом ортографијом, употребом великог слова добија још једно ново значење у енглеском језику.

Када је реч о називима за реалије које нису искључиво везане за православну Цркву, владика Николај је имао избор. Прво, да употреби термине који су познати потенцијалном примаоцу дела у језику превода, што је он најчешће и чинио. С друге стране, постоји велики број примера када је уместо овог користио позајмљеницу, од којих смо 
неке претходно поменули (heguman, skytis, Kinot, и др). Следе још неки примери: $р о p=$ поп (иако постоји реч у енглеском, priest); protopop = протопоп (и поред речи archpriest); sabor = сабор (поред термина synod); Vladika = Владика (овде је користи само у директном говору једног од ликова, иако постоји термин bishop).

На основу ових и сличних примера, закључујемо да је и овакав избор оправдан истим разлозима којим и употреба страних речи у превођењу безеквивалентне лексике. Владика је желео да сачува изворну референцу, да донесе нове информације читаоцу, не само у смислу упознавања са страним термином, већ и обиљем информација којима су најчешће били пропраћени у напомени. То је чинио са мером. „Универзалне", познате термине који умањују референцијалну вредност изворне речи, користио је како читаоца не би сувише оптеретио подацима, изазвао досаду и замор.

У преводу Пролої а на енглески језик наилазимо на нешто другачију ситуацију него што је то био случај са претходно анализираним делом,

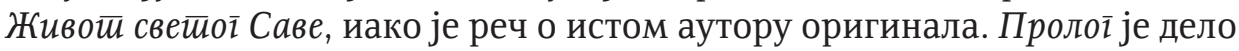
које припада другом жанру, што је први фактор који је утицао на употребу одређених преводилачких поступака. Превод Пролої а, међутим, намењен је пре свега православном вернику и просечном примаоцу. Језик оригинала не користи у великој мери стручну, уско православну црквену терминологију. Пошто је циљ да поучи просечног читаоца а не да му донесе нове стручне, информације, и лексика која доминира је општеупотребна или универзално-хришћанска (карактеристична за све хришћанске конфесије), односно таква за коју је могуће наћи еквиваленте у језику превода. Друго, преводилац у овом случају јесте особа којој је језик превода матерњи језик, а уз то је и добар познавалац православне терминологије.

Процес пресликавања и овде је изостао. Преводилац се труди да што више приближи смисао теста просечном крајњем примаоцу, па ослобађа превод, што ћемо и касније видети свих елемената које би читаоца могле заморити.

Сходно томе, ограничена је и употреба страних речи. Преводилац лако налази еквиваленте речима из оригинала. Стране речи остављене су углавном само кад је у питању стручни назив за одређену реалију специфичну за православље коју не би било пожељно пресвести описно, калком и сл. Такав је случај са називима за посебан вид црквених песама и богослужбених књига, као на пример: kontakion (pl. kontakia) = кондак; akathist = акатист; Irmologion = Ирмологија; Menologion = Meceцослов; stichera = стихира.

Буквалан превод или калк не би на одговарајући начин покрио семантичко поље ових термина у оригиналу, а самом читаоцу не би олак- 
шао разумевање термина. Поред овога, примаоци превода, као група православних верника, којима је превод намењен сасвим сигурно познају значење ових посуђених термина, јер се с њима неминовно срећу у овој форми. Стога преводилац не даје ни додатна објашњења у тексту или у напомени осим у два случаја:

a) код назива богослужбене књиге Octoechos = Октоих, где је у фусноти дато објашњење "the book of the Eight Tones, which change weekly and comprise the basis of the Offices".

б) и код посебног и за литургијски обред основног богослужбеног предмета, antimins = антиминс. Преводилац испод у фусноти објашњава значење овог термина ("a cloth containing relics of the saints that is spread on the Holy Table for the celebration of liturgy").

За термине који следе преводилац је могао изабрати и неки други преводилачки поступак, али се определио за страну реч не би ли ипак указао на специфично православну реалију и тиме задржао референцијално значење оригинала: ascesis = подвиг; prosfora-maker $=$ просфорник (у овом случају је комбиновањем стране и домаће реч добијена нова сложеница - неологизам); skete, scetis = скит; Laurus = лавра; semantron = клепало (Ова реч је објашњена у фусноти - "in Serbian a long piece of wood, shaped for resonance, which is struck rapidly with a mallet. It became widely used in place of a bell under Turkish rule, when Christians were forbidden to ring bells", чиме преводилац уноси нове информације не би ли поучио читаоца о њима далекој српској култури).

Следећи пример показује страно име (надимак) које је прво преведено, а одмах потом у загради дато и у транслитерализованој форми: Holy Father John the Dwarf (Kolobos) = преп. Јован Колов (=Мали).

У ову групу уврстили смо и превод назива празника: the Dormition of the Most Holy Mother of God = Успеније Пресвете Богородице - Овај назив празника је у енглеском језику у овом облику мало познат. Налазимо га ретко у општим речницима енглеског језика. Дат је у Колинсу (Collins English Dictionary 1991: 466), али нас упућује на други термин који је познатији у западном свету, the Assumption. За разлику од општепознатог преводног еквивалента Assumption, који користе католици, термин Dormition карактеристичан је за православно учење, латинског је порекла (dormire) и значи „спавати” или „заспати вечитим сном, умрети". Католичка Црква, наиме, учи да је Мајка Божија жива вазнета, а православна да је умрла а потом узета на небо. Избор термина преноси и разлику у учењу ових двају Цркава.

Ови страни термини прилагодили су се енглеском језику процесима транслитерације (нпр. ascesis, semantron, prosfora), транскрипције (нпр. akathist) или комбинацијом ова два (scetis, stichera). 
Калкирање или буквалан превод овде се користи посебно код „додатних" имена светитеља и Богородичиних икона, што је препоручљиво превести, а не транслитерацијом и транскрипцијом пренети у било који језик превода, јер ова имена јесу попут придева, описују важну карактеристику одређеног светитеља или иконе: St Anastasia the Deliverer from Bonds = света Анастасија Узорешишељьии,; Holy Father Longinus the Lover of Labour = Преподобни Лонгин Tруgољубиви; Holy Father John the Dwarf (Kolobos) = преп. Јован Колов (= Мали); The Mother of God, the Chieftain = Богородица Челнии, ; God-bearer = Богородица.

Редак је пример превођења страног имена одређене географске области, као код: the Holy Mountain = Света Гора; а калкирана је и лексема hieromartyr (= свештеномученик), сложеница сачињена од домаћих елемената.

Поред калкирања кад је реч о превођењу страног имена, преводилац користи и описни поступак, нпр: St. Simon the Outpourer of Myrrh = преп. Симон Мироточиви; St Lazarus the Four-Days-Dead = свети Лазар Четвородневни.

Преводом-дефиницијом пренети су и називи за неке реалије које имају у терминологији православне Цркве посебно значење. За реч јуроguви српски језик користи посебан назив задржан из црквенословенског да би тиме разликовао ово уско значење од општег, наиме „луда”. Енглески језик ово надомешћује тиме што уз реч fool даје и додатно значење које црквенословенски еквивалент у себи носи. Тако добијамо Fool for Christ (sake).

Термин spiritual guide описује реч gуховник који такође има посебно значење у православној Цркви, а енглески еквивалент тиме постаје семантички неологизам, добивши ново значење у контексту текстова из области православне духовности.

Опис је примењен и у превођењу следећих термина: bone-chapel = костурница; fellow-heir (with Christ) = санаследник (Христов); monastery treasurer = манастирски економ; cell-servant = послушник.

Оваквим описним превођењем добијени су неологизми.

Мали број безеквивалентних термина замењен је домаћим аналогним елементом, чиме је у преводу изгубио референцијалну интенцију, односно неутралисао посебан валер који они имају у оригиналу, као у примерима: feast = слава; steward = дохијар, економ.

Можемо закључити, да је у овом случају избор поступака при превођењу такође био условљен жанром и примаоцима превода, али и знањем преводиоца, не само кад је у питању познавање језика превода већ и стручна оспособљеност за превођење оваквих текстова.

У радовима на енглеском језику аутор, односно преводилац примарно се одлучује да задржи основи валер безеквивалентне лексеме 
употребом црквенословенизама и грцизама у виду стане речи и прилагођене процесом транскрипције или транслитерације, а потом и калка, уз додатна објашњења у складу са циљном читалачком публиком.

\section{ИЗВОРИ}

\section{А. Примарни извори}

Велимировић, Николај. Пролої. Линц: Православна црквена општина Линц. 2001. Velimirović, Nikolaj. The Prologue from Ochrid: Lives of the Saints and Homilies for Every Day in the Year. Birmingham: Lazarica Press. 1986.

Velimirović, Nikolaj. The Life of St. Sava. Libertyville: Serbian Orthodox Monastery of St. Sava, 1951.

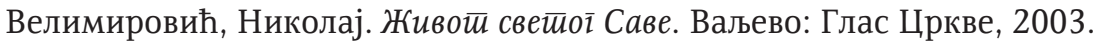

\section{Б. Секундарни извори}

Collins English Dictionary. Glasgow: Harper Collins Publishers, 1991. 466 s.

Microsoft Encarta World English Dictionary, енглеско-енглески речник у електронској верзији

Opći religijski leksikon: A-Ž (glasni urednik Adalbert Rebić). Zagreb: Leksikografski zavod Miroslav Krleža, 2002, 890 s.

\section{ЛИТЕРАТУРА}

Кончаревић, Ксенија. Графијско-ортографска обележја сакралног функционалностилског комплекса у српском и руском језику (из социолингвистичке и нормативистичке перспективе), Зборник Матиие срйске за славистику 75, 2009, 11-38.

Пешикан, Митар/Јерковић, Јован/Пижурица. Правойис срӣской језика, Нови Сад: Матица Српска; Београд: Завод за уџбенике, 2009.

Ракић, Радомир. Неки теоријски и практични аспекти превођења црквенне терминологије. Превоgна књижевносй: зборник раgова XXIII-XXIV беоїраgских ирревоgилачких сусретиа 1997-2001, Београд: Удружење књижевних преводилаца Србије, 2002. стр. 25-37.

Knežević, Ivana/Ranković, Zoran. Ka sakralnom ortografskom standardu - pisanje velikog slova u strogo naučnom podstilu religijskog stila: primeri iz tekstova na srpskom i engleskom jeziku, Komunikacija i kultura online 5,2014, 38-51.

Levi, J. Umjetnost prevođenja. Sarajevo: „Svjetlost”, OOUR Zavod za udžbenike i nastavna sredstva, 1982, 82-83 s.

Hlebec, Boris. Opšta načela prevođenja. Beograd: Naučna knjiga, 1989, 70, 80, 137 s. 
Ivana Knežević

\section{CHURCH SLAVONIC WORDS IN THE WORKS OF BISHOP NIKOLAJ (VELIMIROVIĆ) IN ENGLISH LANGUAGE}

\section{Summary}

In cultures of different nations there are realities specific to the community, which on the linguistic plan reflects in the existence of nonequivalent lexicon. With this work we have tried to study the problems of a translator on encountering nonequivalent vocabulary in the works of Bishop Nikolaj (Velimirović) in Serbian and English languages in the domain of Orthodox religion and spirituality. In addition, we will mention the issue of the deviation from the standard orthographic norm in the aforementioned works.

Key words: translation, nonequivalent vocabulary, Orthodox Christian terms, Church Slavonic words 